Volume 2 Nomor 1, Januari-Juni 2018: hlm. 55-66. Magister Ilmu Hukum, Fakultas Hukum, Universitas Lampung, Bandar Lampung, Lampung, Indonesia.

E-ISSN: 2598-3105 P-ISSN: 2723-2581

http://jurnal.fh.unila.ac.id/index.php/cepalo

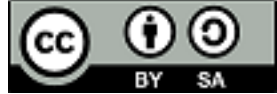

\title{
DUALISME KEWENANGAN PERADILAN DALAM SENGKETA PERBANKAN SYARIAH PASCA KEPUTUSAN MAHKAMAH KONSTITUSI NOMOR 93/PUU-X/2012
}

\section{DUALISM OF JUDICIAL AUTHORITY IN SHARIA BANKING DISPUTES POST CONSTITUTIONAL COURT RULING NUMBER 93/PUU-X/2012}

\author{
Gunawan Raka \\ Gunawan Raka Law Firm \\ Gunawanraka1122@gmail.com
}

\begin{abstract}
Abstrak
Dualisme hukum adalah prinsip yang harus dihindari untuk menghindari kekacauan hukum (legal disorder) dan untuk menciptakan tatanan hukum. Inilah yang terjadi antara Pengadilan Negeri dan Pengadilan Agama di Indonesia, khususnya yang berkaitan dengan Bank Syariah. Setelah dikeluarkannya Keputusan Mahkamah Konstitusi No. 93 / PUU-X / 2012, ini memberikan solusi positif bagi perkembangan perbankan syariah di Indonesia. Hasil keputusan Mahkamah Konstitusi No. 93 / PUU-X / 2012 menjelaskan bahwa: (a) dalam Pengadilan Agama, penyelesaian perselisihan perbankan syariah adalah kedaulatan tetap menurut Mahkamah, (b) dalam perjanjian itu dijelaskan bahwa pihak-pihak yang masuk ke dalam kegiatan Perbankan Syariah (bank dan klien Islam) dapat memilih forum dan ini harus secara jelas dinyatakan dalam perjanjian, (c) ketika membuat perjanjian (perjanjian) harus ada perjanjian antara kedua pihak dan mungkin tidak kontroversial dengan aturan hukum undangan yang sudah ditentukan sebelumnya. Implikasi hukum dari penerbitan Keputusan Mahkamah Konstitusi Nomor 93 / PUU-X / 2012 adalah bahwa: (a) litigasi syariah tentang penyelesaian perselisihan bank menjadi kewenangan absolut pengadilan dalam ruang lingkup pengadilan agama, (b) para pihak dapat menyelesaikan perselisihan melalui Badan Arbitrase Nasional Syariah, dan badan arbitrase lainnya. Penelitian ini dilakukan dengan metode pendekatan yuridis normatif yang digunakan untuk mencari data sekunder yang berhubungan dengan masalah penelitian. Dan penulis menggunakan pendekatan yuridis normatif karena berhubungan dengan permasalahan penelitian.
\end{abstract}

Kata Kunci: Kewenangan, Peradilan Agama, Sengketa.

\begin{abstract}
Legal dualism is a principle that must be avoided to avoid legal disorder and to create a legal order. This is what happened between the District Courts and Religious Courts in Indonesia, especially those relating to Islamic Banks. After the issuance of Constitutional Court Decree No. 93/PUU-X/2012, this provides a positive solution for the development of Islamic banking in Indonesia. The results of the Constitutional Court's decision No. 93/PUU-X/2012 explains that: (a) in the Religious Court, the settlement of Islamic banking disputes is permanent sovereignty according to the Court, $(b)$ in the agreement it is explained that the parties entering into Sharia Banking activities (Islamic banks and clients) can choose a forum and this must be clearly stated in the agreement, (c) when entering into an agreement (agreement) there must be an agreement between the two parties and may not be controversial with the law of invitation that has been predetermined. The legal implications of the issuance of the Constitutional Court Decree No. 93/PUU-X/2012 are that: (a) sharia litigation regarding the settlement of bank disputes becomes the absolute authority of the court within the scope of
\end{abstract}


the religious court, (b) the parties can settle disputes through the Sharia National Arbitration Board, and other arbitration bodies. This research was conducted with a normative juridical approach method that is used to find secondary data related to research problems. And the authors use a normative juridical approach because it deals with research problems.

Keywords: Authority, Religion Courts, Disputes.

Cara Mengutip (How to Cite): Gunawan Raka, "Dualisme Kewenangan Peradilan dalam Sengketa Perbankan Syariah Pasca Keputusan Mahkamah Konstitusi Nomor 93/Puu-X/2012”, Jurnal Cepalo, 2 (1), (2018): 55-66.

DOI: https://doi.org/10.25041/cepalo.v2no1.1762

\section{A. Pendahuluan}

Pertumbuhan ekonomi di Indonesia semakin bertumbuh pesat dan berkembang, termasuk pertumbuhan ekonomi berupa uang, jasa, dan lain sebagainya. Tidak hanya perkembangan ekonomi saja yang berkembang pesat dan mengalami perubahan, begitu juga dengan praktek ekonomi. Salah satunya adalah kegiatan ekonomi dengan menggunakan sistem ekonomi syariah. Perbankan Syariah di Indonesia berkembang secara relevan. Akibat dari perkembangan perbankan syariah yang relevan ini dapat memungkinkan terjadinya perselisihan diantara para pihak yang bersangkutan. Perselisihan dapat terjadi karena adanya ketidaksamaan opini antar kedua belah pihak yang pada akhirnya menimbulkan suatu masalah. Namun terdapat dua cara untuk menyelesaikan suatu sengketa yaitu dengan cara melalui jalur pengadilan (litigasi) dan jalur diluar pengadilan (non litigasi). Cara menyelesaikan perkara di perbankan syariah sendiri telah diatur dalam Pasal 55 ayat (1), ayat (2), dan ayat (3) Undang-Undang Nomor 21 Tahun 2008 tentang Perbankan Syariah (selanjutnya disebut Undang-Undang Perbankan Syariah). Peradilan yang memiliki hak mutlak untuk menyelesaikan perkara perbankan syariah adalah Peradilan Agama, dan hal ini termuat dalam Pasal 55 ayat (1) Undang-Undang Nomor 21 Tahun 2008 tentang Perbankan Syariah. Selanjutnya ketentuan pada Pasal 49 ayat (1) Undang-Undang Nomor 3 Tahun 2006 tentang Peradilan Agama, ${ }^{1}$ menjelaskan bahwa Pengadilan Agama bertugas untuk memeriksa, memutus, dan menyelesaikan perkara di tingkat pertama antara orang-orang yang beragama Islam di bidang ekonomi syariah.

Sedangkan dalam Pasal 55 ayat (2) Undang-Undang Nomor 21 Tahun 2008 tentang Perbankan Syariah dijelaskan bahwa jika para pihak memperjanjikan, maka dapat dilakukan sesuai dengan perjanjian dan sengketa dapat dilakukan dengan melalui litigasi ataupun non litigasi. Contoh jalur litigasi ialah melalui Peradilan Umum, sedangkan jalur non litigasi adalah dengan cara penyelesaian suatu perkara secara kekeluargaan, mediasi ataupun negosiasi, musyawarah mufakat, dan bisa juga melalui Badan Arbitrase Syariah Nasional (Basyarnas). Namun secara yuridis Pasal 55 ayat (2) Undang-Undang Perbankan Syariah dinilai bertentangan dengan Undang-Undang Peradilan Agama, dimana undang-undang yang datang kemudian bisa berlawanan dengan undang-undang sebelumnya yang telah mengatur tentang forum penyelesaian sengketa.

Contoh kasus atas dualisme penyelesaian sengketa sebagaimana tersebut diatas, dapat dilihat dalam beberapa konflik yang terjadi, misalnya di Bank Muamalat Bandung memenangkan nasabah atas kasusnya yang ditangani oleh Basyarnas. Sementara bank yang Basyarnas menangkan adalah bank, dan nasabah pergi ke pengadilan umum negeri. Namun, putusan pengadilan negeri memenangkan nasabah dan timbul perselisihan. Dalam kasus Bank Mandiri Syariah, ada juga kasus yang diselesaikan di Basyarnas dan berhasil dimenangkan oleh nasabah, dan akhirnya Bank Mandiri Syariah mencari cara untuk membuat upaya hukum lainnya, sehingga ada lagi perselisihan yang timbul. ${ }^{2}$

\footnotetext{
${ }^{1}$ Undang-Undang Nomor 7 Tahun 1989 tentang Peradilan Agama telah mengalami dua kali perubahan, yaitu Undang-Undang Nomor 3 Tahun 2006 dan Undang-Undang Nomor 50 Tahun 2009.

${ }^{2}$ Beberapa contoh yang dikemukakan oleh Dr. Syafi'i Antonio sebagai saksi dari pemohon. Lihat Putusan Mahkamah
} 
Konfik kewenangan pengadilan sengketa ekonomi syariah dialami oleh Dadang Achma (Direktur CV. Benua Engineering Consultant) sebagai salah satu nasabah dari Bank Muamalat Cabang Bogor yang merasa hak nya dirugikan. Yang seharusnya sebagaimana telah ditetapkan dalam Undang-Undang setiap orang berhak untuk mendapatkan jaminan kepastian hukum dan perlakuan yang sama dengan seadil-adilnya di hadapan hukum. Kepastian hukum (legal certainty) dimana sengketa ekonomi syariah diadili tidak diperolehnya disebabkan dualisme tempat penyelesaian sengketa perbankan syariah, yakni Peradilan Umum dan Peradilan Agama. Dalam Pasal 49 Undang-Undang Nomor 3 Tahun 2006 tentang Peradilan Agama menjelaskan bahwa "Pengadilan Agama bertugas dan berwenang memeriksa, memutuskan, dan menyelesaikan perkara ditingkat pertama antara orang-orang yang beragama Islam di bidang: perkawinan, waris, wasiat, hibah, wakaf, zakat, infaq, shadaqah, dan ekonomi islam" termasuk didalamnya perbankan syariah, dan hal ini dipertegas dalam Pasal 55 ayat (1) Undang-Undang Perbankan Syariah yang menyebutkan bahwa "penyelesaian sengketa perbankan syariah dilakukan oleh pengadilan dalam lingungan Peradilan Agama.

Peradilan Agama sebagai satu-satunya peradilan sengketa ekonom syariah akhirnya menemukan kepastian hukum setelah terbitnya Keputusan Mahkamah Konstitusi Nomor 93/PUU-X/2012 yakni pada tanggal 29 Agustus 2013. Dengan dikeluarkannya putusan Mahkamah Konstitusi tersebut, menimbulkan berbagai pertanyaan yang dianalisis dalam tesis berjudul "Kewenangan Peradilan Agama Dalam Sengketa Ekonomi Syariah dan Perbankan Syariah Pasca Putusan Mahkamah Konstitusi Nomor 93/PUU-X/2012 mengenai Judicial Reiew atas Undang-Undang Nomor 21 Tahun 2008 tentang Perbankan Syariah.”

Berdasarkan latar belakang diatas, maka penulis akan fokus terhadap dua permasalahan mendasar yaitu; Menganalisa bagaimana tindakan Peradilan Agama dalam menyelesaikan perkara perbankan syariah sejak dikeluarkannya Putusan Mahkamah Konstitusi Nomor 93/PUU-X/2012, dan Keterkaitan hukum dengan terbitnya Putusan Mahkamah Konstitusi Nomor 93/PUU-X/2012. Penelitian ini dilakukan dengan metode pendekatan yuridis normatif yang digunakan untuk mencari data sekunder yang berhubungan dengan masalah penelitian. ${ }^{3}$ Dan penulis menggunakan pendekatan yuridis normatif karena berhubungan dengan permasalahan penelitian.

\section{B. Pembahasan}

\section{Kewenangan Peradilan Agama dalam Menyelesaikan Sengketa Perbankan Syariah Pasca Putusan Mahkamah Konstitusi Nomor 93/PUU-X/2012.}

Perbankan Syariah di Indonesia berkembang secara relevan sejak tahun 1998. Akibat dari perkembangan perbankan syariah yang relevan ini dapat memungkinkan terjadinya perselisihan diantara para pihak yang bersangkutan. Perselisihan dapat terjadi karena adanya ketidaksamaan opini antar kedua belah pihak yang pada akhirnya menimbulkan suatu masalah. Namun, ada dua cara untuk menyelesaikan perselisihan, yaitu melalui pengadilan (litigasi) dan di luar pengadilan (non-litigasi). Likuidasi kasus perbankan syariah paling sering diselesaikan melalui Badan Arbitrase Muamalat Indonesia (BAMUI), yang sekarang dikenal sebagai Badan Arbitrase Syariah Nasional (Basyarnas) dan secara umum, perjanjian antara klien dan bank syariah selalu mencakup klausul arbitrase dan keputusan Basyarnas adalah mutlak dan unik serta hanya melalui proses litigasi di Pengadilan Negeri. Telaah kewenangan Peradilan Agama dimulai dari pemikiran bahwa diundangkannya Undang- Undang Nomor 3 Tahun 2006 adalah pilar sejarah Peradilan Agama diberikan kewenangan baru selain menangani kasus/sengketa perdata keluarga. Atas tugas atau wewenang baru yang diberikan kepada Peradilan Agama, dikeluarkanlah Undang-Undang Nomor 21 Tahun 2008 tentang Perbankan Syariah. Sejak diundangkannya Undang-Undang Nomor 3 Tahun 2006, Peradilan Agama memiliki 3 (tiga) kewenangan baru diantaranya kewenangan menyelesaikan perkara zakat, infaq, dan sengketa ekonomi syariah. Dalam Pasal 49 Undang-Undang Nomor 3 Tahun 2006 disebutkan bahwa

Konstitusi Nomor 93/PUU-X/2012, hlm 21-22.

${ }^{3}$ Abdulkadir Muhammad., Op. Cit., hlm. 134. 
Ekonomi Syariah memiliki ruang lingkup yang luas. Ekonomi syariah merupakan perbuatan atau kegiatan usaha yang dilaksanakan berdasarkan prinsip syariah, meliputi bank syariah, dan lain-lain. Kewenangan dalam menyelesaikan sengketa perbankan syariah ini yang kemudian menimbulkan permasalahan, yaitu ketentuan dalam Pasal 55 ayat (1), (2), dan (3):

Pasal 55

(1) Penyelesaian sengketa perbankan syariah dilakukan oleh pengadilan di lingkungan Peradilan Agama.

(2) Dalam hal para pihak telah memperjanjikan penyelesaian sengketa selain sebagaimana dimaksud dalam ayat (1), penyelesaian sengketa dilakukan sesuai isi akad.

(3) Penyelesaian sengketa selain sebagaimana dimaksud dalam ayat (2) tidak boleh bertentangan dengan prinsip syariah.

Penjelasan Pasal 55

(1) Cukup jelas.

(2) Yang dimaksud dengan "penyelesaian sengketa dilakukan sesuai isi akad" ialah:

a. Musyawarah;

b. Mediasi perbankan;

c. Melalui Badan Arbitrase Syariah Nasiona (Basyarnas), dan/atau lembaga arbitrase lainnya;

d. Melalui pengadilan dalam lingkungan Peradilan Umum.

(3) Cukup Jelas

Terdapat kejanggalan dalam Pasal 5 ayat (2), karena disatu sisi memberikan kekuasaan absolut terhadap Peradilan Agama (Pasal 45 ayat (1)) dan disisi lain juga memberikan kewenangan yang sama pada Peradilan Umum (Pasal 55 ayat (2)). Dan dalam Pasal 55 ayat (2) ini menjelaskan bahwa maksudnya pasal ini memberikan pilihan kepada para pihak untuk membuat forum (choice of forum) untuk memecahkan masalah pada kasus perbankan syariah ini apakah mau diselesaikan dengan proses litigasi atau non litigasi. Pemilihan forum (choice of forum) yang diatur dalam Pasal 55 ayat (2) Undang-Undang Nomor 21 Tahun 2008 dan uraian tentang konflik sehubungan dengan lembaga penyelesaian sengketa sering terjadi antara pengadilan negeri dan pengadilan agama, Basyarnas dengan Pengadilan Negeri atau Pengadilan Agama dengan Basyarnas, ${ }^{4}$ karena konflik ini dapat timbul karena perbedaan pendapat dan juga dengan keinginan para pihak yang belum tercapai.

Pasal 55 ayat (2) Undang-Undang Nomor 21 Tahun 2008 bertentangan dengan UndangUndang Nomor 3 Tahun 2006 tentang Peradilan Agama, dimana dalam pasal tersebut (Pasal 55) mampu menyebabkan kompleksitas hukum karena dalam Pasal 5 ayat (1) dan (2) saling berlawanan. Karena dalam ayat (1) menjelaskan bahwa sengketa perbankan syariah dapat diselesaikan di Peradilan Agama, sedangkan ayat (2) memiliki arti bahwa para pihak berhak untuk melakukan kebebasan dalam melakuka suatu perikatan. Hal ini sebenarnya sudah sejalan dengan asas hukum perikatan dan hukum perjanjian Islam dengan syarat para pihak harus menjalankan hak an kewajibannya sesuai dengan syariat Islam. ${ }^{5}$

Sedangkan dalam Pasal 1338 KUHPerdata ayat (1) menjelaskan bahwa semua perjanjian yang dibuat secara sah berlaku sebagai undang-undang bagi mereka yang membuatnya. Dan maksud dari pasal ini artinya undang-undang memberikan kebebasan untuk melakukan, mengadakan, atau membuat suatu perikatan kepada para pihak yang berssangkutan baik perikatan tersebut berbentuk lisan ataupun berbentuk tulisan. Menurut Subekti, syarat sahnya suatu perikatan ialah klausa yang halal, hal ini terdapat dalam Pasal 1320 KUHPerdata. ${ }^{6}$ Klausa

\footnotetext{
${ }^{4}$ Lihat keterangan ahli yang dihadirkan Mahkamah Konstitusi dalam Perkara Nomor 93/PUU-X/2012.

${ }^{5}$ Faturrahman Djamil, Hukum Perjanjian Syariah dalam Kompilasi Hukum Perikatan, Bandung: Citra Aditya Bakti, (2001), hlm. 249.

${ }^{6}$ Subekti, Hukum Perjanjian, Jakarta: Intermasa, (2001), hlm. 20.
} 
yang dimaksud dalam akad adalah isi atau makna yang terdapat dalam akad tersebut. Pasal 1337 juga menjelaskan kalau suatu klausa dikatakan terlarang apabila tidak sesuai dengan aturan atau norma dalam masyarakat yang dapat mengganggu ketertiban umum atau berlawanan dengan undang-undang.

Pasal 55 ayat (2) dinilai berlawanan dengan Pasal 55 ayat (1) dan berlawanan dengan Undang-Undang Nomor 3 Tahun 2006 tentang Peradilan Agama jika akad yang dibuat tidak sesuai dengan aturan-aturan hukum serta dapat berakibat batal demi hukum. Hakim Agung Gani Abdullah menyebutkan bahwa Pasal 55 ayat (1) adalah merupakan akar pasal yang mengatur kewenangan dan sesuai dengan aturan hukum. Sedangkan Pasal 55 ayat (2) adalah merupakan pasal preferensi dan tidak boleh melenceng daripada akar pasal (yaitu Pasal 55 ayat (1)). ${ }^{7}$ Terdapat suatu aturan yang bersifat ketentuan untuk menghindar dari kondisi yang umum/normal (exilled clausule) atau disebut sebagai ketentuan khusus dari keadaan umum (speciallis clausule) hal ini terdapat dalam Pasal 55 ayat (2) Undang-undang Nomor 21 Tahun 2008. Oleh karena itu dapat di simpulkan bahwa Pasal 55 ayat (2) bersifat exilled clausule dan seharusnya Pasal 55 ayat (2) tersebut lebih baik dihapus/ditiadakan karena sudah jelas ayat tersebut tidak sinkon atau tidak sejalan dengan Pasal 55 ayat (1). Dengan kata lain bahwa pasal 55 ayat (2) merupakan pasal yang lahir karena dipaksakan (contractditio interminis) sehingga untuk mengetahui maksud dari contractditio interminis tersebut harus kembali kepada proses pembentukan undang-undang supaya bisa mencapai norma yang ideal (ideal norm).

Karena pada Pasal 55 ayat (2) tersebut sudah sangat jelas tidak selaras atau tidak sejalan dengan Pasal 55 ayat (1) serta menimbulkan banyak polemik dalam aturan hukum, maka dapat disimpulkan bahwa sudah jelas tidak ada permasalahan atau konflik mengenai perselisihan terhadap kewenangan dalam ayat (2) tersebut diatas. Karena pada hakikatnya ayat (2) tersebut merupakan ayat yang lahir karena dipaksakan, Pasal 55 ayat (2) berbunyi "penyelesaian sengketa dilakukan sesuai isi akad" yang maksudnya cara penyelesaiannya merupakan penyelesaian sengketa dengan cara non litigasi seperti musyawarah, mediasi perbankan, dapat juga melalui badan arbitrase seperti Basyarnas maupun badan arbitrase lainnya, dengan demikian pasal 55 ayat (2) tidak mengurangi pada ketentuan Pasal 55 ayat (1) yang berkaitan dengan kewenangan Peradilan Agama.

Dalam isi pasal 55 ayat (2) memiliki makna bahwa dalam ayat tersebut tidak memiliki kewenangan yang ditujukan kepada peradilan umum tetapi hanya seperti penyelesaian sengketa dengan cara kekeluargaan atau perundingan. Maka dari itu bagi para pihak yang memiliki pendapat bahwa tugas atau kewenangan Peradilan Agama diambil alih oleh peradilan umum ialah sama sekali tidak akurat karena bukan seperti itu hal yang dimaksud di dalam undangundang. Meskipun demikian dalam Pasal 55 ayat (2) tersebut memiliki kalimat bersayap dan multi-eksplanasi. Pemohon mengajukan uji materi terhadap Pasal 55 ayat (2) dan (3) UndangUndang Nomor 21 Tahun 2008 tentang Perbankan Syariah terhdap Pasal 28 ayat (1) UndangUndang Dasar 1945 dengan alasan mendasar yaiu:

a Pada Pasal 28 ayat (1) Undang-Undang Dasar 1945 mengamanatkan bahwa setiap orang berhak pengakuan, jaminan, perlindungan dan kepastian hukum yang adil serta perlakuan yang sama di hadapan hukum, namun kepastian hukum tersebut tidak didapatkan pada ketentuan Pasal 55 ayat (2) Undang-Undang Nomor 21 Tahun 2008 tentang Perbankan Syariah karena mempersilahkan para pihak untuk memilih lembaga peradilan (choice of forum) didalam menyelesaikan sengketanya perbankan syariah dalam perkara yang substansinya sama dan objeknya yang sama pula, apalagi Pasal 55 ayat (3) undang-undang ini menyatakan bahwa penyelesaian sengketa sebagaimana dimaksud pada ayat (2) tidak boleh bertentangan dengan prinsip syariah, sehingga memunculkan pertanyaan apakah lembaga penyelesaian sengketa yang dipilih para pihak sesuai dengan ketentuan Pasal 55 ayat (2) tersebut sudah memenuhi syariah? Padahal ayat lainnya dalam undang-undang perbankan syariah ini tepatnya Pasal 55 ayat (1) undang-undang tersebut secara tegas telah

\footnotetext{
${ }^{7}$ Mimbar Hukum, Edisi 70 Tahun 2010, Pusat Pengembangan Hukum Islam dan Masyarakat Madani (PPHIMM), hlm. 22.
} 
menentukan peradilan mana yang harus digunakan dalam menyelesaikan sengketa perbankan syariah, maka dengan adanya kebebasan memilih tersebut akan menimbulkan berbagai penafsiran dari berbagai pihak dan ketidakpastian hukumnya.

b. Terdapat paradoks antara ketentuan Pasal 55 ayat (1) Undang-Undang Nomor 21 Tahun 2008 dengan yang secara tegas menyebutkan bahwa pengadilan dalam lingkungan peradilan agama yang menyelesaikan sengketa perbankan syariah, dengan ketentuan Pasal 55 ayat (2) dan ayat (3) yang membebaskan para pihak untuk memilih lembaga peradilan mana yang akan mengadili jika terjadi sengketa dalam perbankan syariah yang menurut pemohon dapat diasumsikan boleh memilih peradilan umum bahkan dilingkungan peradilan lain yang disepakati para pihak.

c. Ketidakpastian hukum tersebut nampak dengan dirugikannya pemohon sebagai nasabah bank, yang sengketanya diproses ke Mahkamah Agung guna mengadili konflik kewenangan/kekuasaan antar lembaga peradilan.

Maka dari itu, tepat pada tanggal 29 Agustus 2013 Mahkamah Konstitusi melahirkan Putusan Nomor 93/PUU-X/2012. Pasal yang diuji adalah Pasal 55 ayat (2) dan ayat (30) dari undang-undang tersebut. Isi putusannya yaitu sebagai berikut:

Menyatakan:

\section{Mengadili}

1. Mengabulkan permohonan Pemohon untuk sebagian:

I. Penjelasan Pasal 55 ayat (2) Undang-Undang Nomor 21 Tahun 2008 tentang Perbankan Syariah (Lembaran Negara Republik Indonesia tahun 2008, Nomor 94, Tambahan Lembaran Negara Republik Indonesia Nomor 4867), bertentangan dengan UndangUndang Dasar Negara Republik Indonesia Tahun 1945.

II. Penjelasan Pasal 55 ayat (2) Undang-Undang Nomor 21 Tahun 2008 Nomor 94, Tambahan Lembaran Negara Republik Indonesia Nomor 4867), tidak mempunyai kekuatan hukum yang mengikat.

2. Memerintahkan memuat putusan ini dalam Berita Negara Republik Indonesia sebagaimana mestinya.

3. Menolak permohonan Pemohon untuk selain dan selebihnya.

Putusan Mahkamah Konstitusi Nomor 93/PUU-X/2012 ini merupakan jawaban terhadap uji materi Pasal 55 ayat (2) dan (3) Undang-Undang Nomor 21 Tahun 2008 tentang Perbankan Syariah terhadap Pasal 28 ayat (1) Undang-Undang Dasar 1945. Akan tetapi tidak semua Hakim Mahkamah Konstitusi setuju atas dikeluarkannya keputusan tersebut. Termasuk Hakim Konstitusi Hamdan Zoelva dan Ahmad Fadlil Sumadi karena mereka memiliki alasan yang divegen dan Hakim Konstitusi Muhammad Alim juga mempunyai opini yang berlainan. Atas keputusan Mahkamah Konstitusi tersebut, akhinya menyatakan bahwa tidak ada perubahan yang terjadi didalam Pasal 55 ayat (1), (2), dan (3) Undang- Undang Nomor 21 Tahun 2008, tetapi penjelasan yang diatur dalam Pasal 55 ayat (2) dinyatakan sudah tidak berlaku lagi karena dinilai telah beroposisi terhadap Undang-Undang 1945 serta dinyatakan tidak memiliki kekuatan hukum yang mutlak/absolut.

\section{Keterlibatan Hukum dengan Dikeluarkannya Putusan Mahkamah Konstitusi Nomor 93/PUU-X/2012}

Hal-hal yang dapat disimpulkan dengan dikeluarkannya Putusan Mahkamah Konstitusi Nomor 93/PUU-X/2012 yang menimbulkan munculnya norma/aturan baru dan juga agunan dalam kepastian hukum menurut Pasal 28 ayat (1) Undang-Undang Dasar 1945 yaitu sebagai berikut:

a. Sebelum dikeluarkannya Putusan Mahkamah Konstitusi No. 93/PUU-X/2012, ada banyak argumen tentang tumpang tindih kewenangan dalam menyelesaikan kasus sengketa bank syariah yang menyebabkan ketidakpastian hukum dan juga kerugian. untuk klien dan bank itu sendiri, bahkan dalam UU No. 3. Pada tahun 2006, dinyatakan bahwa pengadilan agama telah menerima kekuasaan absolut untuk menyelesaikan kasus perbankan syariah, termasuk 
ekonomi syariah.

b. Dalam Pasal 55 ayat (1), (2), dan (3) Undang-Undang Nomor 21 Tahun 2008 tentang Perbankan Syariah dan Pasal 49 huruf (i) Undang-Undang Nomor 3 Tahun 2006 tentang perubahan terhadap Undang-Undang Nomor 7 Tahun 1989 tentang Peradilan Agama menjelaskan bahwa pada hakikatnya mereka memberikan para pihak kebebasan dalam menylesaikan perkaranya yang harus sesuai dengan prinsip syariah yang dibuat dalam bentuk tertulis/kontrak dan dalam isi kontrak tersebut harus terdapat hak dan kewajiban para pihak untuk menyelesaikan perkaranya tersebut. Dan dalam pasal 55 ayat (1), (2), dan (3) Undang-Undang Nomor 21 Tahun 2008 tentang Perbankan Syariah dan Pasal 49 huruf (i) Undang-Undang Nomor 3 Tahun 2006 tentang perubahan terhadap Undang-Undang Nomor 7 Tahun 1989 tentang Peradilan Agama telah memberikan kekuasaan kepada Pengadilan dalam lngkungan Peradilan Agama untuk menyelesaikan kasus Perbankan Syariah.

c. Secara struktural, pilihan para pihak untuk memilih forum hukum harus sesuai dengan kontrak, dan pilihan forum hukum adalah pilihan alternatif jika para pihak yang berselisih dalam perbankan Islam tidak ingin perselisihan diselesaikan dalam kondisi litigasi hukum yang telah ditentukan. ${ }^{8}$

Akad berasal dari kata al aqd yang mempunyai beberapa arti diantaranya mengikat, memperkuat, mempererat. Secara umum yang dimaksud dengan akad adalah setiap yang mengandung tekad seseorang untuk melakukan sesuatu. Baik tekad tersebut dari satu pihak, maupun adanya respon dari pihak lain yang memiliki kehendak sama, yang menunjukkan keingian kuat untuk melakukan akad (perikatan).

Pasal 1 angka 5 Undang-Undang Nomor 19 Tahun 2008, mendefinisikan bahwa akad adalah suatu kontrak yang berbentuk tertulis serta tidak berlawanan dengan aturan-aturan islam/syariah dan harus sesui juga dengan peraturan perundang-undangan yang mutlak. ${ }^{9}$ Sedangkan Pasal 1 angka 13 Undang-Undang Nomor 21 Tahun 2008 menyebutkan bahwa akad adalah kesepakatan atau persetujuan antara Bank Syariah dengan pihak lain yang isinya menjelaskan tentang hak-hak dan kewajiban para pihak dalam akad tersebut yang harus sesuai dengan prinsip-prinsip syariah. ${ }^{10}$ Dalam Kitab Undang-Undang Hukum Perdata (KUHPerdata) menjelaskan bahwa akad juga setara dengan kontrak/perikatan/perjanjian yang berkaitan dengan analisis hukum perdata. Dan dalam KUHPerdata sendiri pengertian akad adalah suatu perbuatan antara satu orang atau lebih untuk mengikatkan diri secara hukum. ${ }^{11}$

Dalam perjanjian, akad memiliki asas-asas, yaitu sebagai berikut: ${ }^{12}$

a. Al Huriyyah (Kebebasan Berkontrak)

Islam memiliki kebebasan individu untuk memiliki, memproduksi dan mengkonsumsi. Setiap individu memiliki kebebasan untuk melakukan pembelian dan penjualan serta menentukan harga dalam berbagai persyaratan nominal, dengan ketentuan yang tidak bertentangan dengan kepentingan publik. Prinsip kebebasan kontrak juga merupakan prinsip paling dasar dari suatu kontrak atau perjanjian. Dalam ekonomi Islam, kebebasan sangat penting karena jika kontrak itu sah atau tidak dalam kebebasan untuk melanjutkan atau tidak melanjutkan kegiatan ekonomi. Akan tetapi bukan berarti kebebasan berkontrak dalam hal ini kita dapat melakukannya dengan tidak berdasarkan aturan, tetapi kebebasan disini memiliki arti bebas dalam melakukan kegiatan ekonomi dengan tetap berlandaskan aturan-aturan atau prinsip syariah dan juga undang-undang. Asas kebebasan berkontrak dalam ekonomi syariah ini juga memiliki fungsi untuk menjamin adanya keterikatan antara para pihak supaya para pihak dapat

\footnotetext{
${ }^{8}$ Lihat Abdul Manan, Penyelesaian Sengketa Ekonomi Syariah, Sebuah Kewenangan Baru Peradilan Agama, dalam Mimbar Hukum, Edisi 73 tahun 2011, Pusat Pengembangan Hukum Islam dan Masyarakat Madani (PPHIMM), hlm 20-35.

${ }^{9}$ Tim Penyusun, Kompilasi Perundang-Undangan tentang Ekonomi Syariah, Pusat Riset dan Data Ekonomi Syariah (Prides), Jakarta, 2008, hlm, 76.

${ }^{10}$ Ibid., hlm. 5.

${ }^{11}$ Handri Raharjo, Hukum Perjanjian di Indonesia, Yogyakarta: Pustaka Yustitia, (2009), hlm. 41

${ }^{12}$ Pasal 20 Kompilasi Hukum Islam.
} 
taat terhadap isi kontrak/akad tersebut. Dalam melakukan asas kebebasan berkontrak para pihak bebas melakukan kontrak engan siapapun, bebas untuk menentukan objek dalam kontrak, dan juga bebas untuk memilih bagaimana cara menyelesaikan masalah apabila terjadi perselisihan diantara kedua belah pihak. Dan dalam melakukan hal-hal tersebut diatas haruslah tetap berpegang teguh terhadap prinsip-prinsip atau aturan-aturan islam. Serta dalam melakukan suatu kontrak meskipun didalamnya terdapat asas kebebasan, tetap harus beralaku jujur dan adil tidak boleh melakukannya dibawah tekanan, berbohong, melakukan penipuan, serta tindak kejahatan lainnya yang dapat merugikan pihak lain. Dasar hukum mengenai asas kebebasan ini termuat dalam kitab suci Al-Qur'an Surat Al-Baqarah yat 256.

\section{b. Al-Musawah (Persamaan atau Kesetaraan) ${ }^{13}$}

Al-Musawah adalah kesejajaran, artinya tidak ada pihak yang merasa lebih tinggi dari yang lain sehingga dapat memaksakan kehendaknya. Dalam asas ini menjelaskan bahwa para pihak yang melakukan perjanjian sama-sama memiliki hak dan kewajiban serta kedudukan yang sama dalam membuat perjanjian dan dalam memutuskan suatu perkara. Dan asas ini terdapat pula didalam surat Al-Hujurat ayat 13.

\section{c. Al-Adalah (Keadilan)}

Al-' 'adalah adalah keadilan, yang berarti bahwa menghormati hukum dan keputusan untuk membuat perjanjian atau kontrak harus dilakukan dengan cara yang adil dan bijaksana, tidak secara sepihak. Dan itu tidak bisa merugikan partai. Arti pentingnya membela keadilan ditegaskan oleh Allah SWT dalam beberapa ayat-Nya, antara lain dalam surat An-Nahl ayat 90: "Sesungguhnya Allah menyuruh (kamu) berlaku adil dan berbuat kebajikan, memberi kepada kaum kerabat, dan Allah melarang berbuat keji, kemungkaran dan permusuhan".

\section{d. Al-Ridha (Kerelaan)}

Maksud dari asas ini adalah setiap aktivitas ekonomi syariah atau perjanjian yang telah dibuat harus pada dasar kerelaan antara para pihak, yakni kerelaan dari sejak membuat perjanjian yang dianggap sebagai syarat terwujudnya seluruh kegiatan ekonomi/transasksi. Dan tidak boleh melakukan perjanjian dibawah tekanan, adanya paksaan yang dapat merugikan pihak yang lainnya.

\section{e. Ash-Shiddiq}

Ash-Shiddiq ialah orang yang membenarkan perkataannya dengan perbuatannya. AlHasan Al-Bashri menuturkan bahwa, "Iman itu bukan karena hiasan dan angan-angan, tetapi iman adalah apa yang terpendam di dalam hati dan dibenarkan perbuatan." Hubungannya dalam kegiatan ekonomi adalah, Islam dengan tegas melarang umatnya untuk berbohong ataupun melakukan penipuan dalam bentuk apapun, hal ini dilarang keras karena dapat merusak kontrak perjanjian yang telah dibuat, karena dalam melakukan sebuah kontrak harus ada sikap jujur dan saling percaya antara para pihak. Dalam Kompilasi Hukum Ekonomi Syariah asas ini disebut juga sebagai asas Transparansi atau disebut juga asas keterbukaan, artinya para pihak harus saling memiliki rasa bertanggungjawab secara terbuka dan supaya terhindar dari berbagai macam kontemplasi. Maka dari itu dalam melakukan perjanjian haruslah didasari dengan sikap yang jujur dan adil, Allah juga sangat membenci dengan orang yang melakukan kebohongan seperti terdapat dalam Surat An-Nahl Ayat 105 yang artinya: Sesungguhnya yang mengada-adakan kebohongan, hanyalah orang-orang yang tidak beriman kepada ayat-ayat Allah, dan mereka itulah orang-orang pendusta.

\section{f. Al-Kitabah (Tertulis)}

Dalam melakukan suatu kontrak pada umumnya dilakukan atau dibuat secara tertulis dan

\footnotetext{
${ }^{13}$ Dalam Kompilasi Hukum Islam Asas Musawah disebut dengan Asas Taswiyah.
} 
ini merupakan salah satu kewajiban dalam melakukan kontrak. ${ }^{14}$ Asas tertulis juga dibuat dengan tujuan sebagai alat bukti jika sewaktu-waktu terjadi hal-hal persengketaan. Dan dalam membuat perjanjian juga harus terdapat saksi-saksi untuk kepentingan pembuktian apabila terjadi perselisihan nantinya.

Dalam suatu perjanjian terdapat beberapa asas yaitu:

\section{a. Prinsip Kebebasan Kontrak}

Prinsip kebebasan kontrak tercantum dalam Pasal 1338 KUH Perdata, yang menyatakan: "Semua perjanjian yang dibuat secara hukum berlaku sebagai hukum bagi mereka yang membuatnya." Prinsip ini adalah prinsip yang memberi kebebasan kepada para pihak untuk:

1) membuat atau tidak membuat perjanjian;

2) membuat perjanjian dengan siapa pun;

3) menentukan perjanjian, implementasi dan persyaratan dari isi perjanjian, serta

4) Tentukan bentuk perjanjian, apakah tertulis atau lisan.

\section{b. Prinsip Konsensualisme}

Prinsip konsensualisme dapat disimpulkan dalam Pasal 1320 ayat (1) KUHPerdata, dalam artikel ini ditentukan bahwa salah satu persyaratan hukum perjanjian adalah kata perjanjian antara kedua pihak. Prinsip ini adalah prinsip yang menetapkan bahwa perjanjian tidak dipelihara secara formal, tetapi dengan kesepakatan antara kedua pihak. Perjanjian tersebut adalah perjanjian antara kehendak dan deklarasi yang dibuat oleh kedua belah pihak. Prinsip konsensualisme yang dikenal dalam KUH Perdata terkait dengan bentuk kesepakatan.

\section{c. Prinsip Mengikatnya Perjanjian (pacta sunt servanda)}

Prinsip keamanan hukum, juga dikenal sebagai prinsip pacta sunt servanda, adalah prinsip yang terkait dengan konsekuensi perjanjian. Prinsip pacta sunt servanda adalah prinsip bahwa hakim atau pihak ketiga harus menghormati isi kontrak yang dibuat oleh para pihak, sebagaimana layaknya sebuah undang-undang. Mereka tidak dapat campur tangan dalam dana kontrak yang dibuat oleh para pihak. Prinsip pacta sunt servanda dapat disimpulkan dalam pasal 1338 ayat (1) KUHPerdata.

\section{d. Prinsip Itikad Baik (Good Faith)}

Prinsip itikad baik ditetapkan dalam pasal 1338 ayat (3) KUHPerdata, yang menyatakan: "Perjanjian harus dilakukan dengan itikad baik." Prinsip ini adalah prinsip bahwa para pihak, yaitu kreditor dan debitor, harus menerapkan substansi kontrak berdasarkan kepercayaan atau itikad baik. liburan. Prinsip itikad baik dibagi menjadi dua jenis, yaitu niat baik relatif dan niat baik mutlak. Pada intensi pertama, seseorang memperhatikan sikap dan perilaku nyata dari subjek. Dalam niat kedua, evaluasi didasarkan pada akal sehat dan keadilan, dan tindakan objektif diambil untuk mengevaluasi situasi (penilaian yang tidak memihak) sesuai dengan norma-norma objektif.

\section{e. Prinsip Kepribadian}

Prinsip kepribadian adalah prinsip yang menentukan bahwa seseorang yang akan membuat dan / atau membuat kontrak hanya untuk kepentingan pribadi. Ini dapat dilihat pada Pasal 1315

\footnotetext{
${ }^{14}$ Faturrahman Djamil, Hukum Perjanjian Syariah dalam Mariam Darus Badrulzaman, Kompilasi Hukum Perikatan Citra Aditya Bakti, Bandung, 2001, hlm 249-251. Lihat hasanudin, Bentuk-Bentuk Perikatan (Akad) dalam Ekonomi Syariah dalam Kumpulan Makalah Ekonomi Syariah, Direktorat Jendral Badan Peradilan Agama Mahkamah Agung RI. 2007, hlm 238-240. Lihat Gemala Dewi dkk, Hukum Perikatan di Indonesia, hlm 31-37. Lihat Syamsul Anwar, Hukum Perjanjian Syariah Studi tentang Teori Akad dalam Fikih Muamalat, hlm 84, 87, 90, dan 92, dan Lihat Mahkamah Agung RI, Kompilasi Hukum Ekonomi Syariah, Pusat Pengkajian Hukum Islam dan Masyarakat Madani, Jakarta, 2009, hlm 20-22.
} 
dan Pasal 1340 KUHPrdt. Pasal 1315 KUHPrdt menyatakan:

"Secara umum, seseorang tidak bisa masuk ke dalam perjanjian atau kesepakatan yang selain untuk dirinya sendiri."

Dalam posisinya, perjanjian tersebut hampir sama dengan hukum, karena keduanya merupakan sumber hukum dari suatu perjanjian. Sehingga dapat dikatakan bahwa perjanjian tersebut memiliki kekuatan hukum yang sama dengan undang-undang. ${ }^{15}$ Meskipun begitu, terdapat pula perbedaan yang dimiliki antara perjanjian dengan Undang- Undang, yaitu:

1) Hukum perjanjian pada dasarnya hanya harus dipatuhi oleh pihak yang bersangkutan saja, sedangkan undang-undang harus dipatuhi oleh publik.

2) Hal-hal yang substansial hanya mengatur para pihak saja sejak dibuatnya perjanjian, sedangkan undang-undang memberikan konsesi untuk hal-hal yang akan datang.

3) Perjanjian hanya ditaati para pihak yang bersangkutan dengan sukarela, sedangkan undangundang mengikat bagi siapapun sehingga semua individu wajib menaati hukum erundangundangan yang berlaku.

\section{Penutup}

Berdasarkan hasil pengkajian dan pendalaman tentang Putusan Mahkamah Konstitusi Nomor 93/PUU-X/2012 menghasilkan konklusi, yaitu: (a) penyelesaian sengketa Perbankan Syariah merupakan kewenangan yang telah ditetapkan dan diberikan kewenangannya kepada Peradilan Agama, (b) pilihan forum hukum dapat dilakukan oleh para pihak yang bersangkutan yang tidak ingin melalui jalur litigasi, (c) hak-hak dan kewajiban yang dimuat dalam perjanjian tidak boleh berlawanan dengan aturan-aturan didalam undang-undang yang telah ditetapkan. Keterkaitan dengan dikeluarkannya Putusan Mahkamah Konstitusi Nomor 93/PUU-X/2012, adalah: (a) berdasarkan hasil putusan tersebut diatas bahwa penyelesaian sengketa perbankan syariah hanya dapat dilakukan di peradilan agama dan keputusan ini bersifat tetap, (b) selain dengan jalur litigasi, para pihak juga dapat menyelesaikan perkaranya melalui Badan Arbitrase Syariah Nasional ataupun badan arbitrase lainnya.

\section{A. Buku}

\section{DAFTAR PUSTAKA}

Djamil, Faturrahman. (2001). Hukum Perjanjian Syariah dalam Kompilasi Hukum Perikatan. Bandung. Citra Aditya Bakti.

Hasanudin. (2007). Bentuk-Bentuk Perikatan (Akad) dalam Ekonomi Syariah dalam Kumpulan Makalah Ekonomi Syariah, Direktorat Jendral Badan Peradilan Agama Mahkamah Agung RI.

Mahkamah Agung RI. (2009). Kompilasi Hukum Ekonomi Syariah. Jakarta: Pusat Pengkajian Hukum Islam dan Masyarakat Madani.

Manan, Abdul. (2012). Hukum Perbankan Syariah, Jurnal Mimbar Hukum dan Peradilan, Pusat Pengembangan Hukum Islam dan Masyarakat Madani, Edisi No. 7.

Permana, Sugiri. (2005). Kedudukan Undang-Undang dan Perjanjian dalam Menentukan Penyelesaian Sengketa Perbankan Syariah oleh Peradilan Agama, Peradilan Umum dan Lembaga Non Litigasi. Yogyakarta: Politea Press.

Raharjo, Handri. (2009). Hukum Perjanjian di Indonesia, Yogyakarta: Pustaka Yustitia.

Subekti. (2001). Hukum Perjanjian. Jakarta: Intermasa.

Tim Penyusun. (2008). Kompilasi Perundang-Undangan tentang Ekonomi Syariah. Jakarta: Pusat Riset dan Data Ekonomi Syariah (Prides).

15 Sugiri Permana, Kedudukan Undang-Undang dan Perjanjian dalam Menentukan Penyelesaian Sengketa Perbankan Syariah oleh Peradilan Agama, Peradilan Umum dan Lembaga Non Litigasi, Yogyakarta: Politea Press, (2005), hlm 12. 


\section{B. Peraturan Perundang-Undangan}

Keputusan Mahkamah Konstitusi Nomor 93/PUU-X/2012.

Kompilasi Hukum Ekonomi Syariah.

Undang-Undang Nomor 3 Tahun 2006 tentang Peradilan Agama.

Undang-Undang Nomor 50 Tahun 2009 tentang Peradilan Agama.

Undang-Undang Nomor 7 Tahun 1989 tentang Peradilan Agama. 
